Dept. of Microbiology and Animal Hygiene.

Fac. Vet. Med., Alexandria University,

Head of Dept. Prof. Dr. M.A. Akeila.

\title{
STUDIES ON THE ROLE OFSTRAY DOGS AS CARRIERS FOR SOME BACTERIAL AND MYCOTIC PATHOGENES TO MAN AT BEHERA GOVERNORATE
} (With 3 Tables)
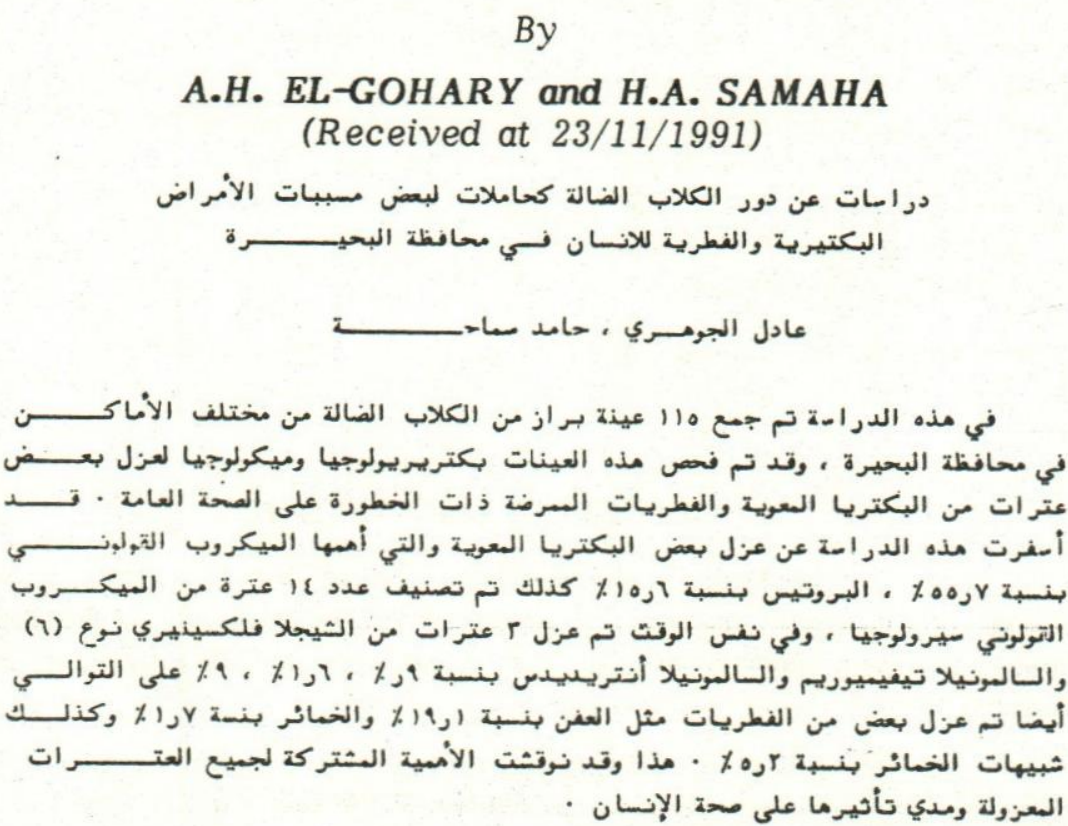

\section{SUMMARY}

One hunderd and fifteen faecal samples were collected from stray dogs at various localities of Behera Governorate, particularly from Edfina, El-Mahmodia and Damanhour localities, as well as especially from those gaining access to human garbage. These samples were examined bacteriologically and mycologically for isolation some members of Enterobacteriaceae and pathogenic fungi of public health hazard. The most predominant bacterial isolates were E.coli $(55.7 \%)$, Proteus spp. $(15.6 \%)$, Enterobacter spp. (11.3\%), Citrobacter freundi (6.9\%) and Klebsiella pneumoniae (2.6\%). The 14 pathogenic strains of E.coli recognized (21.9\%) were differentiated serologically into the following O-serogroups: 02, 04, 06, 015, 011, 026 and 0101. At thesame time three important human pathogens: Shigella flexineri type 6, Sal. typhimurium and Sal. enteritidis were recovered 


\section{EL-GOHARY \& SAMAHA}

in an incidence of $0.9,1.7$ and $0.9 \%$ respectively. The results of mycological investigation revealed that the incidence of the isolates were Mould spp. (19.1\%), Yeast spp. (1.7\%) and Yeast-like organisms (5.2\%). The zoonotic importance of these isolates was discussed.

\section{INTRODUCTION}

Stray dogs constitute one of the most important public health hazardous problems which may suffer from systemic or localized infection with some pathogenic bacteria and fungi. Besides being infected with various agents of zoonotic significance however, they may act as symptomless and excretors of many pathogenic microorganisms leading to severe human infections. A fact which is substan'iated on the base of many available reports (REFAI \& LOOT, 1969; HUBBERT \& ROSEN, 1970; ROSEN, 1971; SMITH, 1971; MAREK et ai., 19:3; SIAM et al., 1973; BOARGOB, 1975; MORSE \& JUNCAN, 1975 and TIMBS et al.. 1975).

The aim of this investigation is to throw light on the role iff stray dogs as carriers of certain human pathogens of family Enterobacteriacess and some pathogenic fungi.

\section{MATERIAL and METHODS}

A total of 115 random faecal samples were obtained from apparently healthy stray dogs in different districts at Behera Governorate. All samples were collected aseptically and sent immediately to the laboratory for bacteriological and mycological examination.

The methods used for identification of Gram-negative isolates were carried out according to the schemes described by EDWARD'S and EWING (1972) and BUCHANAN \& GIBBONS (1974). Serological typing of the isolated Saimonella, Shigella and pathogenic E.coli was induced by using the rapid slide agglutination test as described by EDW ARD and EWING (1972). Polyvalent antisera against Salmonella serogroups were obtained from serotherapeutic institute, Fac. of Vet. Med., Vienna 'Jniversity.

Identification of the recovered moulds was carried out according to SAMSON (1979). While the isolated yeasts were identified according to LODDER (1971) and ARX et al. (1977).

\section{RESULTS}

The results are tabulated in Tables (1, 2 \& 3 ;

\section{DISCUSSION}

The 64 E.coli existed in $(55.7 \%)$ isolated in this work, were differentiated into $50(78.1 \%)$ non-pathogenic and $14(21.9 \%)$ pathogenic E.coli serologically typed into

Assiut Vet.Med.J. Vol. 26, No. 52, January, 1992. 


\section{STRAY DOGS AS CARRIERS OF PATHOGENS}

7 0-serogroups: 02, 04, 06, 011, 015, 026 and 0101 (Table 2). These findings are more or less coinside with that obtained by SOJKA (1965) and RENAULT et al. (1975). However, E.coli is known to be the major causative agent of diarrhea, uro-genital affection and haemorrhagic colitis in humans (ORSKOV et al., 1972; LOEWENSTEIN et al., 1973 and ABRAHAM et al., 1983) as well as gastroentritis in dogs (LING et al., 1979).

The recovery of the four species of Proteus (Table 1), Proteus vulgaris (7.8\%) and Proteus mirabilis (5.2\%) were the most predominant species. These findings support the results obtained by ABDEL-FATTAH (1977) who isolated the four species from the faeces of apparently healthy dogs. However, these organisms were recovered from cases of summer diarrhoea among infants and urinary tract infection (BANWART, 1981).

Shigella flexneri type 6 was isolated at an incidence of $0.9 \%$ (Table 1). These result was agreed with TIWARY and PRASAD (1972). However, infection with Shigella and Salmonella in stray dogs might be a result of their coprophagous habit. Regarding to public health importance dogs may act as a transient excretors of this organisms in highly endemic areas of human shigellosis in addition Shigella flexneri causing food borne gastroenteritis (BANW ART, 1981).

Salmonella typhimurium and Sal. enteritidis were isolated at pərcentages of $1.7 \%$ and $0.9 \%$ respectively (Table 1 ). This result came in agreement with GOLEBIOWSKI (1975). who isoalted the organism from liver and faeces of one dog. However, both organisms are known members of humman food poisoning bacteria (EMARA et al., 1950).

Klebsiella pneumoniae was detected in $2.6 \%$ (Table 1 ). This organism is considered as pathogen and potentially pathogens in cases of acute pneumonia, bacteraemia, urinary tract and several other types of human infections in man (LIMSON et al., 1956 and BERGEY'S, 1984).

From the results tabulated in Table (3) it revealed that the predominant mould genera were Aspergillus niger (7.8\%) followed by A. flavus (5.2\%), A. fumigatus (1.7\%) and Mucor spp. (4.4\%). Aspergillus spp. have been incriminated as causative agonts in many human mycotic infections especially broncho-pulmonary aspergillosis (JORDAN et al., 1971).

As illustrated in Table (3), the incidence of Candida albicans was (3.5\%) followed by C. tropicalis (1.7\%). From the public health point of view, candida infection is responsible for Thrush of the mouth particularly in debilitated infants (MARPLES, 1960), also it is a common cause of vaginitis and vulvovaginitis in women (RAUT, 1971). Moreover, Rhodotorula mueilaginosa isolated (1.7\%) Table (3) which incriminated in human mycosis (RIETH, 1973).

From the results achieved, one may safely conclude that apparently normaly stray dogs in Behera Governorate may harbour a variety of bacterial and mycotic pathogens constituting a potential health hazard to other animals and man.

Assiut Vet.Med.J. Vol. 26, No. 52, January, 1992. 


\section{EL-GOHARY \& SAMAHA}

\section{REFERENCES}

Abdel-Fattah, M.Z. (1977): A contribution towards the genus Proteus in domestic animals. M.V.Sc. Thesis, Cairo University.

Abraham, E.; Brenner, B.E. and Simon, R.R. (1983): Cystitis and pyelonephritis. Ann. Emerg. Med. 12, 228-234.

Arx,J.A. Von; De Miranda, R.; Smith, M. Th. and Yarrow, D. (1977): The genera of yeast and the yeast like fungi. Centerbureau Voor Schimmelcultures, Baarn. studies in mycology No. 14, 130-133.

Banwart, G.J. (1981): "Basic food microbiology". Avi Publishing Company. Inc., Westport, Cannacticut. P. 125-126.

Bergey's Manual ofSystemic Bacteriology (1984): Vol. 1. 8th Ed. The Williams and Wilkins. Baltimore. London.

Boargob, A. (1975): Studies on the Salmonella counts in naturally and experimentally infected dog faeca! samples. Ing. Diss. Berlin.

Buchanan, R.E. and Gibbons, N.E. (1974): Bergey's manual of determinative bacteriology 8th Ed., williams \& wilkins Company, Baltimore.

Dold, H. and Fisher, W. (1921): Zentbl. Jakt., Parasitkd., I. 215-218.

Edwards, P.R. and Ewing, W.H. (1972): Identification of Enterobacteriaceae 3rd Ed., 67-107. Burgess, Publishing Co., Minneapolis.

Emara, M.; Moustafa, M.N. and Elyan, A.S. (1950): Articles of food responsible for food poisoning in Egypt. J. Roy. Egyptin Med. Ann. 33: 361-369.

Golebiowski, S. (1975): Carrier state of Salmonella, Shigella, Past. multocida and Erysipelothrix insidiosa in dogs. Medycyna Waterynaryino, 31: 523-526.

Hubbert, W.T. and Rosen, M.N. (1970): Pasteurella multocida infection due to animal bite. Am. J, Publ. Health. 60: 1103-1108.

Jordan, M.C.; Bierman, C.W. and Van Arsdel, P.P. (1971): Allergic broncho-pulmonary Aspergillosis. Arch. Intrin. Med. 128(4): 576-580.

Limson, B.M.; Romansky, M. and Shea, J.G. (1956): Ann. Intern. Med., 44: 1070-1074. (Cited in Topley \& Wilson's Principles of Baceeriology, Virology and immunity, by Wilson, G.F. \& Miles,A.A. 6th Ed. Vol. I. Arnold, London).

Ling, G.V.: Ribestein, E.L. and Hirth, D.C. (1979): Bacterial pathogens associated with urinary tract infections. North Am. Small Anim. Pract. 9: 617-630.

Lodder, J. (1971): The yeast. North Holland. Pub. Co. Ams., London.

Loewenstein, M.S.; Balows,A. and Gangarosa, A.J. (1973): Lancet, 1: 529-531.

Marples, J. (1960): Some extra human reservoirs of pathogenic fungi in Newzealand. Trans-Roy. Soc. Trop. Med. Hyg. 25: 216-220.

Marek, P.; Magana, F. and Abikiti, R. (1973): A survey of the incidence of Salmonellosis in Northen Tanzania. Ind. J. Anim. Sc., 43: 7.

Morse, E.V. and Duncan, M.A. (1975): Canine salmonellosis, prevalence, epizootiology, signs and public health significance. J. Am. Vet. Med. Ass. 167: 817-820.

Assiut Vet.Med.J. Vol. 26, No. 52, January, 1992. 


\section{STRAY DOGS AS CARRIERS OF PATHOGENS}

Orskov, F.; Orskov, I. and Furowiez, A.J. (1972): Acta. Path. Microbiol. Scand. B. 80: 435-438. (Cited in Topley \& Wilson's Principles of Bacteriology, Virology and Immunity byWillson, C.S. \& Miles, A.A., 6th Ed. Vol. 2, Arnold, London).

Raut, M. (1971): Clinicopathological study of leucorrhoea. J. Indian Med. Assoc., 56: 7-9.

Refai, M. and Loot, A. (1969): Studies of mould contamination of meat in slaughter houses, butcher's shops and in cold stores. Mykosen, 12(10): 621-624.

Renault, L.; Schaetz, N.; Vozenin, S. and Guellot, M.H. (1975): Role of E.coli ingastroenterities in the dogs. Animal de Compagnie, Il: 95.

Rieth, H. (1973): Zur Diagnostik Und Therapic der Mykosendurch Imperfecte. Hafen. Archiv. Klin. Exp. Derm, 20\& 348-350.

Rosen, M.N. (1971): Infectious and parasitic diseases of wild birds. lowa State 6th Ed. college Press, Ames, lowa.

Samson, R.A. (1979): A compilation of the Aspergillus described since 1965. Studies in mycology No. 1\& 1-38.

Siam, M.A.; Abdel-Karim, A.M.; Hamed, O.M. and Zakaria, A. (1973): The possible role ofstray dogs and cats in the epidemiology of some bacterial human pathogens in Egypt. Zbl. Vet. Med. B. 20: 409-419.

Smith, H.W. (1971): The bacteriology of the alimentary tract ofdomestic animals sufering from E.coli infection. Ann. N.Y. Acad. Sci., 176: 110-125.

Sojka, W.J. (1965): Escherichia coli in domestic animals and poultry. Forunham Royal, 3th Ed. Commonwealth Agr. Bureaux.

Timbs, D.V.; Davis, G.B.; Carter, M.E. and Carman, M.G. (1975): The Salmonella excretor incidence of dogs in Hawkes Bay. Newzealand Vet. J. 23: 54-56.

Tiwary, B.K. and Prasad, L.B.M. (1972): Enteric infection in live stock and poultry caused by Salmonella and Shigella. Vet. Rec., 91: 510-513.

Assiut Vet.Med.J. Vol. 26, No. 52, January, 1992. 


\section{EL-GOHARY \& SAMAHA}

Table 1: Number and incidence of identified pathogenic members of Enterobacteriaceae islated from faeces of stray dogs.

\begin{tabular}{|c|c|c|c|c|c|}
\hline Isolates & No. & $\%$ & O-Serotypes & $\begin{array}{l}\text { No. of } \\
\text { isolates }\end{array}$ & $\%$ \\
\hline Escherichia coli & 64 & 55.7 & 02 & 3 & 4.7 \\
\hline Proteus vulgaris & 9 & 7.8 & 04 & 3 & 4.7 \\
\hline Proteus mirabilis & 6 & 5.2 & 0606 & 2 & 3.1 \\
\hline Proteus morgani & 2 & 1.7 & 011 & 1 & 1.6 \\
\hline Proteus rettgeri & 1 & 0.9 & 015 & 2 & 3.1 \\
\hline Enterobacter spp. & 13 & 11.3 & 026 & 1 & 1.6 \\
\hline Citrobacter freundi & 8 & 6.9 & 0101 & 2 & 3.1 \\
\hline Aerobacter aerogenes & 1 & 0.9 & non-pathogenicE.coli & 50 & 78.1 \\
\hline Klebsiella pneumoniae & 3 & 2.6 & & & \\
\hline $\begin{array}{l}\text { Providencia spp. } \\
\text { Salmonella typhimurium }\end{array}$ & $\begin{array}{l}4 \\
2\end{array}$ & $\begin{array}{l}3.5 \\
1.7\end{array}$ & Total & 64 & 100.0 \\
\hline $\begin{array}{l}\text { Salmonella typhimurium } \\
\text { Salmonella enteritidis }\end{array}$ & 1 & 0.9 & & & \\
\hline Shigella flexneri type 6 & 1 & 0.9 & & & \\
\hline Total & 115 & 100.0 & & & \\
\hline
\end{tabular}

Table 2: 0-Serotypes and their incidence of pathogenic E.coli in faeces of dogs.

Table 3: Number and incidence of identified Mould and Yeast isolated from faeces of stray dogs.

\begin{tabular}{lll}
\hline \multicolumn{1}{c}{ Isolates } & No. & $\%$ \\
\hline Mould spp.: & & \\
\hline Aspergillus niger & 9 & 7.8 \\
Aspergillus flavus & 6 & 5.2 \\
Aspergillus fumigatus & 2 & 1.7 \\
Mucor spp. & 5 & 4.4 \\
Yeast spp: & & \\
\hline Rhodotorula mucilaginosa & 2 & 1.7 \\
Yeast-like organisms: & & \\
\hline Candida albicans & 4 & 3.5 \\
Candidatropicalis & 2 & 1.7 \\
\hline \multicolumn{1}{c}{ Total } & 30 & 26.0 \\
\hline
\end{tabular}

Assiut Vet.Med.J. Vol. 26, No. 52, January, 1992. 